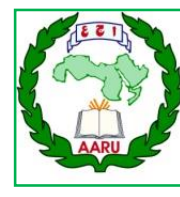

Arab Univ. J. Agric. Sci., Ain Shams Univ., Cairo, Egypt

28(4), 1031-1039, 2020

Website: http://ajs.journals.ekb.eg

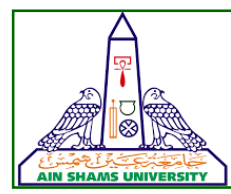

1031

\title{
Effect of Some Plant Extracts on Hyperprolactinemia in
} Experimental Animals

\author{
Anan A Mohamed ${ }^{\star}$, Magde F Tawfik, Hemmat A Ibrahim, \\ Farouk G. Moawad
}

Biochemistry Dept., Fac. of Agric., Ain Shams Univ., P.O. Box 68, Hadayek Shoubra 11241, Cairo, Egypt

*Corresponding author: Ananatef1994@gmail.com

Received 8 September, 2020

Accepted 14 November, 2020

\begin{abstract}
Hyperprolactinaemia is the occurrence of an endocrine disorder that leads to an increase in the level of the hormone prolactin (PRL) in the blood above normal levels in cases other than the natural increase in pregnancy and lactation. It may be present as the menstrual disturbances, galactorrhea, sexual dysfunction, gynecomastia, infertility, decreased bone mineral density, and breast cancer. This increase results from several causes that may be pathological such as pituitary tumors, psychological such as stress, or as a result of taking a specific drug such as schizophrenia, anti-vomiting drugs, nerve analgesics, first-generation antipsychotics, hypnotics, and sedatives. Hyperprolactinaemia by metoclopramide was induced in male and female rats to assess the therapeutic effects of alcoholic extracts of sage leaves, marjoram leaves and celery seeds. Through the biochemical analysis of blood hormones, the results showed that treating rats with metoclopramide drug (150 mg / kg / day) for a week had an effect on the positive control group in the occurrence of hyperprolactinaemia compared to the negative control group at the beginning of the experiment. The results indicated that there was a significant effect $(P<0.05)$ for the three plant extracts namely marjoram leaves, sage leaves and celery seeds ( $250 \mathrm{mg} / \mathrm{kg} /$ day) for 30 days, to reduce the prolactin hormone in the blood and also to maintain the level of the rest of the sex hormones (progesterone (PRG), estrogen (E2), testosterone (TST), Follicle-stimulating hormone (FSH) and Luteinizing hormone (LH)) without causing any disturbance in males and females in comparison to the group of drug used in the experiment. To treat this condition
\end{abstract}

bromocriptine (Dopamine receptors agonist) is used. The rats returned to normal case after the appearance of the rats' recovery after taking the extracts during the trial period. This effect may be due to estrogen receptors and /or dopamine receptor.

Keywords: Hyperprolactinaemia, Prolactin hormone, Metoclopramide, Sage, Marjoram, Celery

\section{Introduction}

Hyperprolactinemia is the presence of high concentrations of the hormone prolactin in the blood beyond its normal limits in cases other than pregnancy and lactation. The rate of the hormone in the blood in women is $25 \mathrm{ng} / \mathrm{ml}$ (Casanueva et al 2006). The causes of hyperprolactinemia are divided into physiological causes (such as pregnancy, lactation, sexual intercourse, and sleep) or due to taking some medications and drugs (such as antipsychotics and antiemetic drugs) or pathological causes (such as the occurrence of tumors in the pituitary gland and the resulting damage to the pituitary gland) (Brue et al 2007). Clinical symptoms of hyperprolactinemia include galactorrhea, menopause, and late pregnancy (Jackson et al 1985). Hyperprolactinemia can occur due to normal body changes during pregnancy and lactation, or because of patients such as diseases affecting the hypothalamus and the pituitary gland, or because of an imbalance in the normal regulation of prolactin levels by medicinal herbs, medicines and heavy metals inside the body, and it may also occur due to diseases in other organs such as the liver, kidney, thyroid and ovary (Mancini et al 2008). 
Prolactin hormone is a polypeptide hormone and contains 199 amino acids. It expresses one of the hormones of the growth family and also the family of sex hormones (Haddad et al 2004). It is mainly secreted from the mammary glands located in the frontal lobe of the pituitary gland and is also produced in other places of the body, such as fat cells in the tissues under the skin, breast and in the visceral tissues. This hormone plays an essential role in pregnancy, lactation, reproduction, and participates in many other vital functions (Ben-Jonathan et al 2006) Stress is one of the most important factors that affect the concentration of the hormone prolactin in the blood, whether that stress is psychological or physiological, and for this reason, prolactin can be called the stress hormone (Falkenius-Schmidt et al 2005).

Metoclopramide is used in the treatment of gastro-inflammatory, indigestion and GERD cases, and it is considered an anti-vomiting agent for many gastrointestinal disorders, and its effect is due to the inhibition of dopamine receptors (Harrington et al 1983). The use of metoclopramide causes a severe increase in the concentration of the hormone prolactin in the blood, which leads to the occurrence of hyperprolactinemia (Amaral et al 2003). Metoclopramide is used in the treatment of psychotic patients, as it is an antipsychotic and acts as an antidopamine receptor antagonist, especially type D2 (Agovic et al 2008).

Bromocriptine is a dopamine agonist and works by inhibiting prolactin release by binding to dopamine receptors of the type D2 (Iván et al 2005). It is a stimulant for dopamine receptors and is widely used in the treatment of pituitary tumors, as it has been shown to inhibit tumors alone from spreading (Shun-Li Zhang et al 2019).

Marjoram is a perennial herb that is native to the Mediterranean countries by the ancient Greeks, Romans and Egyptians, and it was used very widely in folk medicine to treat many diseases because it has antioxidant and antimicrobial properties (Prerna and Vasudeva 2015). It contains high concentrations of essential oils, and a high percentage of thymol and carvacrol, as they are very high antioxidants (Potty 2001).

Sage- (Salvia officinalis L.) is a perennial round shrub in the family of Labiatae/Lamiaceae. It is found in the Middle East and Mediterranean regions and has a long history in folk medicine and cooking. It has been used in the treatment of ulcers, disorders, gout, seizures, rheumatism, tremors, paralysis, diarrhea, high blood sugar, as well as treating mild indigestion and sweating (Bisset and Whichtl
2001). Recently, many researches have been done on sage, and it has led to many results in its ability to treat cancers, and it is considered anti-inflammatory, analgesic, anti-oxidant, anti-fungi and anti- microbial (Perry et al 1999).

Celery (Apium graveolens L.) is grown in Europe then began spreading all over the world for its high nutritional properties. All of its parts leaves, stems and seeds are used for cooking because they are rich in many elements proteins, vitamins, carotenoids, fibres, phenolics, flavonoids and tannins with flavouring and health properties (Ovodova et al 2009). It treats many diseases as it is considered a diuretic, anti-seizure, and laxative, and is used in the treatment of diabetes (Yusni et al 2018).

The effect of plant extracts of marjoram leaves, sage leaves, and celery seeds on hyperprolactinemia and the efficacy of these extracts compared to the biochemical drugs used in treating this disease was monitored by estimating the levels of hormones in the blood (PRL, FSH, LH, Progesteron, E2 and tostosteron).

\section{Materials and Methods}

\subsection{Materials}

Marjoram (Origanum majorana) leaves Sage (Salvia officnalis) Leaves; and Celery (Apium graveolens) seeds were purchased from Agricultural Seeds, Spices and Medicinal Plants Co., El-Azhar St., Cairo, Egypt. Metoclopramide (primperan) was obtained from SANOFI Egypt Co., Cairo, Egypt. Ethanol $70 \%$ was purchased from El-Nasr Chemical Co., Cairo, Egypt. All other chemicals used in this work were of analytical grade.

\subsection{Reagent kits}

Prolactin, follicle stimulating hormone (FSH), luteinizing hormone (LH), progesterone, testosterone and estrogen (E2) kits were obtained from Egyptian Company for Biotechnology, Obour city, Industrial area, block 19A, Kalubia, Egypt.

\subsection{Methods}

\subsubsection{Preparation of plant extracts}

Marjoram leaves, sage leaves and celery seeds were macerated in ethanol $70 \%$ for 24 hours at room temperature. The ethanolic extracts were filtered and evaporated to dryness under vacuum; the residues were kept in deep freezer $-18^{\circ} \mathrm{C}$ until used (Tsai et al 2004). 


\section{Effect of Some Plant Extracts on Hyperprolactinemia in Experimental Animals}

\subsubsection{Biological evaluation}

\subsubsection{Experimental animals}

Sixty males and females albino rats of Wistar strain weighing about $100 \mathrm{~g}$ were obtained from the National Research Center, Dokki, Giza, Egypt. The rats were housed under normal laboratory conditions. The rats had free access to food and water ad libitum during the experimental period.

\subsubsection{Experimental design}

Rats were randomly divided into 12 groups (5rats/group) 6 males and 6 females. The first group in both males and females was negative control. Five other groups of males and 5 groups of females were oral treated by an anti-dopamine drug metoclopramide (150 mg / kg/day) for one week. Group 2 of treated male and female rats were left without any treatment for comparison (positive control), group 3 of treated males and females rats were given a chemo-lowering hormone namely lactodel for comparison, while groups $(4,-5$ \& 6) were administered with marjoram leaves, sage leaves and celery seeds extracts by the stomach tube with a concentration of $250 \mathrm{mg} / \mathrm{kg} /$ day for 30 days. Prolactin hormone was analyzed for all groups to confirm the incidence of infection compared to negative control after giving metoclopramide and before giving the extracts, and at the end of the experiment also to evaluate the results ( $\mathrm{Li}$ et al 2015).

\subsubsection{Blood sampling and biochemical assays}

Blood samples were taken after a week of administration rats with metoclopramide and again at the end of the experiment. The blood samples were obtained from retro-orbital vein by using capillary tubes. The blood was centrifuged at $4000 \mathrm{rpm}$ to obtain the serum which was kept in a freezer $\left(-18^{\circ} \mathrm{C}\right)$ until use for biochemical analysis and hormone assayes. Hormon assayes of PRL, E2, progesterone, $\mathrm{FSH}, \mathrm{LH}$ and testosterone were measured using ELISA kits as stated by (Li et al 2015).
2.3.3 Determination of hormones Prolactin (PRL), follicle stimulating hormone(FSH), luteinizing hormone $(\mathrm{LH})$, progesterone $(\mathrm{Pg})$, estrogen (E2) and testosterone (TST) as followes

\subsubsection{Principle of the Assay}

This ELISA kit uses Competitive-ELISA as the method. The microtiter plate provided in this kit has been pre-coated with an antibody specific to Prl. During the reaction, Prl in the sample or standard competes with a fixed amount of biotin-labeled Prl for sites on a pre-coated Monoclonal antibody specific to Prl. Excess conjugate and unbound sample or standard are washed from the plate, and HRPStreptavidin Conjugate (SABC) is added to each microplate well and incubated. Then a TMB substrate solution is added to each well. The enzyme-substrate reaction is terminated by the addition of a sulphuric acid solution and the color change is measured spectrophotometric ally at a wavelength of 450 $\mathrm{nm}$. The concentration of $\mathrm{Prl}$ in the samples is then determined by comparing the O.D. of the samples to the standard curve (Wuhan boster Biological Engineering Co, Ltd).

\section{The method can be summaried as follows}

1. Wash plate 2 times before adding standard, sample and control (zero) wells!

2. Add $50 \mu \mathrm{L}$ standard or sample to each well.

3. Immediately add $50 \mu \mathrm{L}$ Biotin- labeled Antigen to each well.

4. Incubate for 45 minutes at $37^{\circ} \mathrm{C}$.

5. Aspirate and wash 3 times.

6. Add $100 \mu \mathrm{L}$ SABC working solution to each well. Incubate for 30 minutes at $37^{\circ} \mathrm{C}$.

7. Aspirate and wash 5 times.

8. Add $90 \mu \mathrm{L}$ TMB Substrate. Incubate 15-20 minutes at $37^{\circ} \mathrm{C}$.

9. Add $50 \mu \mathrm{L}$ Stop Solution. Read at 450nm immediately.

10. Calculate results.

\subsubsection{Statistical analysis}

Results are presented as means \pm standard error of three replicates. The recorded data were treated statistically using one way analysis of variance (ANOVA). The means were compared by least significant difference test (LSD) at $\mathrm{P}<0.05$. Statistical analyses were performed using SPSS statistical software (IBM SPSS Statistics, version 20) (Snedecor and Cochran 1980). 


\section{Results and Discussion}

3.1 Curative effect of alcoholic extracts of marjoram leaves, celery seeds and sage leaves on the levels of PRL, FSH and LH hormones in serum of male rats affected with hyperprolactinemia induced by metoclopramide

Table 1 demonstrates the therapeutic effects of alcoholic extracts marjoram leaves, sage leaves and celery seeds on the levels of the hormones $\mathrm{PRL}, \mathrm{FSH}$ and LH compared to the effect of the biochemical drug used in treating this condition at the end of the experiment ( 30 days) in male rats infected with hyperprolactinemia. The results showed a significant difference $(P<0.05) A$ decrease was shown in the level of prolactin in rats treated with plant extracts of sage leaves $(11.4 \mathrm{ng} / \mathrm{ml})$ and celery seeds $(9.6 \mathrm{ng} / \mathrm{ml})$ compared to the negative control group $(10.5 \mathrm{ng} / \mathrm{ml})$ and there was no significant difference $(P<0.05)$ between negative control $(10.5$ $\mathrm{ng} / \mathrm{ml}$ ) and rats treated with marjoram leaves (10.7 $\mathrm{ng} / \mathrm{ml}$ ) extract, but there was significant difference $(P<0.05)$ between the treatment with the three extracts and the positive control group $(17.9 \mathrm{ng} / \mathrm{ml}) \mathrm{a}$ significant difference $(P<0.05)$. This effect may be attributed to the phytoestrogens present in these plants or dopamine receptors. Also, there was a significant difference $(\mathrm{P}<0.05)$ of prolactin hormone in the rats treated with the drug used in comparison with the positive control group $(17.9 \mathrm{ng} / \mathrm{ml})$, but statistical analysis showed that the efficiency of reducing the hormone by plant extracts was significantly higher than the efficiency of reduction by the used drug. The results also showed a significant difference $(\mathrm{P}<0.05)$, in FSH levels between the negative control group $(7.9 \mathrm{IU} / \mathrm{L})$ and rats treated with marjoram leaves $(7.4 \mathrm{IU} / \mathrm{L})$ and sage leaves $(6.4 \mathrm{IU} / \mathrm{L})$ extracts, but there was no significant difference $(P$ $<0.05)$ between it and the rats treated with celery seeds extract (7.8 IU/L); they were all within the limits of the normal proportions of the hormone in the body. Also, a significant difference $(P<0.05)$ was observed in the $\mathrm{LH}$ hormone in the three groups treated with plant extracts (marjoram leaves (4.6 $\mathrm{IU} / \mathrm{L})$, sage leaves (4.1 IU/L) and celery seeds $(4.7 \mathrm{IU} / \mathrm{L}))$ compared to the negative control group $(4.5 \mathrm{IU} / \mathrm{L})$, in spite of that, they were within the limits of levels of hormone levels in the blood. This means that the extracts showed the same efficiency in their therapeutic effect of hyperprolactinemia and no harmful effect on the rest of the hormones compared to the drug used in the treatment. There was a significant difference $(P<0.05)$ between group treated by bromocriptine $(12.5 \mathrm{ng} / \mathrm{ml})$ and the group treated by celery $(9.6 \mathrm{ng} / \mathrm{ml})$. There was no significant difference $(P<0.05)$ between the group treated by bromocriptine $(12.5 \mathrm{ng} / \mathrm{ml})$ and the group treated by sage $(11.4 \mathrm{ng} / \mathrm{ml})$ and marjoram $(10.7 \mathrm{ng} / \mathrm{ml})$ these results are in line with those of Stahl et al (1998), Toru Oda et al (2008) and Al-Asmari et al (2017).

Table 1. Curative effect of alcoholic extracts of marjoram leaves, celery seeds and sage leaves on the levels of PRL, FSH and $\mathrm{LH}$ hormones in serum of male rats affected with hyperprolactinemia induced by metoclopramide

\begin{tabular}{|c|c|c|c|}
\hline Groups & $\begin{array}{c}\text { PRL } \\
(\mathbf{n g} / \mathbf{m l})\end{array}$ & $\begin{array}{c}\text { FSH } \\
(\mathbf{I U} / \mathbf{L})\end{array}$ & $\begin{array}{c}\text { LH } \\
(\mathbf{I U} / \mathbf{L})\end{array}$ \\
\hline Control & $10.5 \pm 0.35^{\mathrm{cd}}$ & $7.9 \pm 0.23^{\mathrm{a}}$ & $4.5 \pm 0.29^{\mathrm{ab}}$ \\
\hline Metoclopramide & $17.9 \pm 0.17^{\mathrm{a}}$ & $5.2 \pm 0.20^{\mathrm{d}}$ & $3.0 \pm 0.14^{\mathrm{c}}$ \\
\hline Bromocriptine & $12.5 \pm 0.26^{\mathrm{b}}$ & $6.9 \pm 0.24^{\mathrm{bc}}$ & $5.0 \pm 0.14^{\mathrm{a}}$ \\
\hline Sage & $11.4 \pm 0.75^{\mathrm{bc}}$ & $6.4 \pm 0.08^{\mathrm{c}}$ & $4.1 \pm 0.18^{\mathrm{b}}$ \\
\hline Celery & $9.6 \pm 0.37^{\mathrm{d}}$ & $7.8 \pm 0.17^{\mathrm{a}}$ & $4.7 \pm 0.2^{\mathrm{a}}$ \\
\hline Marjoram & $10.7 \pm 0.26^{\mathrm{cd}}$ & $7.4 \pm 0.21^{\mathrm{ab}}$ & $4.6 \pm 0.15^{\mathrm{ab}}$ \\
\hline
\end{tabular}

The data are presented as means \pm SE calculated from three replicates. Different letters refer to significant differences at $(P<0.05)$.

3.2 Curative effect of alcoholic extracts of marjoram leaves, celery seeds and sage leaves on the levels of PRG, EST and TST hormones in serum of male rats affected with hyperprolactinemia induced by metoclopramide

The data in Table 2 indicate that the therapeutic effect of the three extracts in question. There was no significant difference $(\mathrm{P}<0.05)$ between the negative control group $(1.3 \mathrm{ng} / \mathrm{ml})$ and the marjoram leaves $(1.2 \mathrm{ng} / \mathrm{ml})$ and celery seeds $(1.1 \mathrm{ng} / \mathrm{ml})$, of the alcoholic extract of marjoram leaves, sage leaves and celery seeds on the rest of the reproductive hormones group. There was a significant difference $(P<0.05)$ between negative control group (1.3 $\mathrm{ng} / \mathrm{ml}$ ) and sage $(0.86 \mathrm{ng} \mathrm{ml})$. All of them were within the normal limits for the hormone progesterone, and same case with the hormone EST. The results indicated that there was no significant difference $(P$ 


\section{Effect of Some Plant Extracts on Hyperprolactinemia in Experimental Animals}

$<0.05)$ between the negative control group $(7.4$ $\mathrm{ng} / \mathrm{ml})$ and the extract of marjoram $(6.9 \mathrm{ng} / \mathrm{ml})$ and celery $(7.0 \mathrm{ng} / \mathrm{ml})$, there was a significant difference $(P<0.05)$ between negative control group (7.4 $\mathrm{ng} / \mathrm{ml})$ and sage $(6.0 \mathrm{ng} \mathrm{ml})$ and also the presence of a significant percentage difference. Also, TST results indicated that there was no significant difference $(P<0.05)$ between the three extracts under trial marjoram $(4.6 \mathrm{ng} / \mathrm{ml}$, celery $(4.6 \mathrm{ng} / \mathrm{ml})$ and sage $(3.9 \mathrm{ng} / \mathrm{ml})$ and the negative control group (4.4 $\mathrm{ng} / \mathrm{ml}$ ), which confirms the safety of using the extracts without harming the rest of the hormones and the effect on individuals. It has also been observed that in the group for which biochemical treatment is used, the level of hormones is not changed. It has a significant difference $(P<0.05)$ between it and the negative control group. There was no significant difference $(P<0.05)$ between group treated by bromocriptine $(4.5 \mathrm{ng} / \mathrm{ml})$ and the group treated by celery $(4.6 \mathrm{ng} / \mathrm{ml})$, sage $(3.9 \mathrm{ng} / \mathrm{ml})$ and marjoram (4.6 $\mathrm{ng} / \mathrm{ml}$ ) these data are similar to those of $\mathrm{Li}$ et al (2015).

Table 2. Curative effect of alcoholic extracts of marjoram leaves, celery seeds and sage leaves on the levels of PRG, EST and TST hormones in serum of male rats affected with hyperprolactinemia induced by metoclopramide

\begin{tabular}{|c|c|c|c|}
\hline Groups & $\begin{array}{c}\text { PRG } \\
(\mathbf{n g} / \mathrm{ml})\end{array}$ & $\begin{array}{c}\text { EST } \\
(\mathbf{n g} / \mathrm{ml})\end{array}$ & $\begin{array}{c}\text { TST } \\
(\mathbf{n g} / \mathrm{ml})\end{array}$ \\
\hline Control & $1.3 \pm 0.12^{\mathrm{a}}$ & $7.4 \pm 0.29^{\mathrm{a}}$ & $4.4 \pm 0.26^{\mathrm{ab}}$ \\
\hline Metoclopramide & $0.76 \pm 0.08^{\mathrm{c}}$ & $6.0 \pm 0.11^{\mathrm{b}}$ & $3.2 \pm 0.17^{\mathrm{c}}$ \\
\hline Bromocriptine & $1.1 \pm 0.08^{\mathrm{ab}}$ & $7.3 \pm 0.23^{\mathrm{a}}$ & $4.5 \pm 0.2^{\mathrm{ab}}$ \\
\hline Sage & $0.86 \pm 0.03^{\mathrm{bc}}$ & $6.0 \pm 0.24^{\mathrm{b}}$ & $3.9 \pm 0.12^{\mathrm{b}}$ \\
\hline celery & $1.1 \pm 0.12^{\mathrm{ab}}$ & $7.0 \pm 0.14^{\mathrm{a}}$ & $4.6 \pm 0.14^{\mathrm{a}}$ \\
\hline Marjoram & $1.2 \pm 0.05^{\mathrm{a}}$ & $6.9 \pm 0.14^{\mathrm{a}}$ & $4.6 \pm 0.08^{\mathrm{a}}$ \\
\hline
\end{tabular}

The data are presented as means \pm SE calculated from three replicates. Different letters refer to significant differences at $(P<0.05)$
3.3 Curative effect of alcoholic extracts of marjoram leaves, celery seeds and sage leaves on the levels of PRL, FSH and LH hormones in serum of female rats affected with hyperprolactinemia induced by metoclopramide

Data in Table 3, which was conducted on female rats infected with hyperprolactinemia, using alcoholic extracts of sage leaves, marjoram leaves, and celery seeds on the prolactin hormone group indicated that there was no significant difference $(P<0.05)$ between the negative control group $(13.8$ $\mathrm{ng} / \mathrm{ml})$ and the groups treated with marjoram(12.7 $\mathrm{ng} / \mathrm{ml})$, and celery seeds since the value was (12.7 $\mathrm{ng} / \mathrm{ml})$, there was a significant difference $(\mathrm{P}<0.05)$ between the negative control group $(13.8 \mathrm{ng} / \mathrm{ml})$ and sage $(15.5 \mathrm{ng} / \mathrm{ml})$, which indicates the efficiency of the extract in reducing the percentage of prolactin hormone from the positive control group(23.4 $\mathrm{ng} / \mathrm{ml})$, which had a significant difference $(\mathrm{P}<0.05)$ with the deficiency, and the results also showed a significant difference $(P<0.05)$ with the increase between the negative control group $(13.8 \mathrm{ng} / \mathrm{ml})$ and the sage extract $(15.5 \mathrm{ng} / \mathrm{ml})$ group, and the presence of a significant difference $(P<0.05)$ with the deficiency between the positive control group and the sage leaves extract group. This indicates the similarity of the marjoram extract $(12.7 \mathrm{ng} / \mathrm{ml})$ and celery extract $(12.7 \mathrm{ng} / \mathrm{ml})$ in reducing the prolactin hormone, and the lesser of them is the efficiency of the sage extract. The results also showed that there was no significant difference $(P<0.05)$ between the extracts of the three plants on FSH hormone, as they preserved the hormone level in the blood without an imbalance compared to the negative control group $(11.3 \mathrm{IU} / \mathrm{L})$. The value of $\mathrm{FSH}$ was in drug group (9.5 IU/L) and when the rats' administrated sage was (10.3 IU/L), marjoram was $(10.0 \mathrm{IU} / \mathrm{L})$ and celery was (10.4 IU/L). However, the LH hormone, the data indicated that there was no significant difference $(P<0.05)$ between the negative control group7.5 IU/L) and the two groups of marjoram (7.6 $\mathrm{IU} / \mathrm{L})$ and sage $(7.9 \mathrm{IU} / \mathrm{L}$ )and the presence of a significant difference $(P<0.05)$ in the deficiency between the negative control group and the celery extract group $(6.3 \mathrm{IU} / \mathrm{L})$, all within the limits of the normal proportions of hormones, which confirms the efficiency of the extracts in treatment without affecting the rest of the hormones in the body Al-Asmari et al (2017) and Toru Oda et al (2008). 
Table 3. Curative effect of alcoholic extracts of marjoram leaves, celery seeds and sage leaves on the levels of PRL, FSH and LH hormones in serum of female rats affected with hyperprolactinemia induced by metoclopramide

\begin{tabular}{|c|c|c|c|}
\hline Groups & $\begin{array}{c}\text { PRL } \\
(\mathbf{n g} / \mathbf{m l})\end{array}$ & $\begin{array}{c}\text { FSH } \\
(\mathbf{I U / L})\end{array}$ & $\begin{array}{c}\text { LH } \\
(\mathbf{I U} / \mathbf{L})\end{array}$ \\
\hline Control & $13.8 \pm 0.52^{\mathrm{c}}$ & $11.3 \pm 0.87^{\mathrm{a}}$ & $7.5 \pm 0.29^{\mathrm{a}}$ \\
\hline Metoclopramide & $23.4 \pm 0.64^{\mathrm{a}}$ & $7.1 \pm 0.59^{\mathrm{c}}$ & $4.5 \pm 0.14^{\mathrm{c}}$ \\
\hline Bromocriptine & $13.4 \pm 0.4^{\mathrm{c}}$ & $9.5 \pm 0.56^{\mathrm{b}}$ & $8.1 \pm 0.11^{\mathrm{a}}$ \\
\hline Sage & $15.5 \pm 0.37^{\mathrm{b}}$ & $10.3 \pm 0.51^{\mathrm{ab}}$ & $7.9 \pm 0.23^{\mathrm{a}}$ \\
\hline celery & $12.7 \pm 0.17^{\mathrm{c}}$ & $10.4 \pm 0.43^{\mathrm{ab}}$ & $6.3 \pm 0.08^{\mathrm{b}}$ \\
\hline Marjoram & $12.7 \pm 0.36^{\mathrm{c}}$ & $10.0 \pm 0.37^{\mathrm{ab}}$ & $7.6 \pm 0.17^{\mathrm{a}}$ \\
\hline
\end{tabular}

The data are presented as means \pm SE calculated from three replicates. Different letters refer to significant differences at $(P<0.05)$.

\subsection{Curative effect of alcoholic extracts of mar- joram leaves, celery seeds and sage leaves on the levels of PRG, EST and TST hormones in se- rum of female rats affected with hyperprolac- tinemia induced by metoclopramide}

To complete the above, data for the rest of the reproductive hormones of the female rats infected with hyperprolactinemia treated with alcoholic extracts of both marjoram leaves, sage leaves and celery seeds, the data in Table 4 indicated that there was no significant difference $(P<0.05)$ in the $P R G$ hormone between the negative control group (1.8 $\mathrm{ng} / \mathrm{ml})$ and the three extract treated groups marjoram $(1.7 \mathrm{ng} / \mathrm{ml})$, celery $(1.7 \mathrm{ng} / \mathrm{ml})$ and sage $(1.9$ $\mathrm{ng} / \mathrm{ml})$, as well as in EST, there was no significant difference $(P<0.05)$ between the negative control group $(6.7 \mathrm{ng} / \mathrm{ml})$ and the three extract treated groups marjoram $(6.9 \mathrm{ng} / \mathrm{ml})$, celery $(7.4 \mathrm{ng} / \mathrm{ml})$ and sage $(7.1 \mathrm{ng} / \mathrm{ml})$, and group treated by bromocriptine $(6.3 \mathrm{ng} / \mathrm{ml})$. The plant extracts have proven their ability to reduce the prolactin hormone without compromising the rest of the sex hormones, so as not to imbalance them, which leads to many problems. In TST hormone there was no significant difference $(\mathrm{P}<0.05)$ between the negative control group $(0.61$ $\mathrm{ng} / \mathrm{ml})$ and marjoram $(0.57 \mathrm{ng} / \mathrm{ml})$, sage $(0.63$ $\mathrm{ng} / \mathrm{ml}$ ) and group treated by bromocriptine (0.57 $\mathrm{ng} / \mathrm{ml})$. There was a significant difference $(\mathrm{P}<0.05)$ between the negative control group $(0.61 \mathrm{ng} / \mathrm{ml})$ and celery $(0.51 \mathrm{ng} / \mathrm{ml})$, which indicates that the extracts did not affect the normal hormone level in the blood, Li et al (2015).

Table 4. Curative effect of alcoholic extracts of marjoram leaves, celery seeds and sage leaves on the levels of PRG, EST and TST hormones in serum of female rats affected with hyperprolactinemia induced by metoclopramide

\begin{tabular}{|c|c|c|c|}
\hline Groups & $\begin{array}{c}\text { PRG } \\
\left(\mathbf{n g} / \mathrm{ml}^{2}\right.\end{array}$ & $\begin{array}{c}\text { EST } \\
(\mathbf{n g} / \mathrm{ml})\end{array}$ & $\begin{array}{c}\text { TST } \\
(\mathbf{n g} / \mathrm{ml})\end{array}$ \\
\hline Control & $1.8 \pm 0.15^{\mathrm{ab}}$ & $6.7 \pm 0.3^{\mathrm{bc}}$ & $0.61 \pm 0.018^{\mathrm{b}}$ \\
\hline Metoclopramide & $2.3 \pm 0.26^{\mathrm{a}}$ & $8.2 \pm 0.14^{\mathrm{a}}$ & $0.71 \pm 0.014^{\mathrm{a}}$ \\
\hline Bromocriptine & $1.6 \pm 0.23^{\mathrm{b}}$ & $6.3 \pm 0.15^{\mathrm{c}}$ & $0.57 \pm 0.018^{\mathrm{bc}}$ \\
\hline Sage & $1.9 \pm 0.17^{\mathrm{ab}}$ & $7.1 \pm 0.17^{\mathrm{b}}$ & $0.63 \pm 0.012^{\mathrm{b}}$ \\
\hline celery & $1.7 \pm 0.25^{\mathrm{b}}$ & $7.4 \pm 0.18^{\mathrm{b}}$ & $0.51 \pm 0.005^{\mathrm{c}}$ \\
\hline Marjoram & $1.7 \pm 0.2^{\mathrm{b}}$ & $6.9 \pm 0.17^{\mathrm{bc}}$ & $0.57 \pm 0.026^{\mathrm{bc}}$ \\
\hline
\end{tabular}

The data are presented as means \pm SE calculated from three replicates. Different letters refer to significant differences at $(P<0.05)$.

Finally, the alcoholic extracts of marjoram leaves, sage leaves and celery seed showed a therapeutic effect against hyperprolactinemia in the blood caused by administration of rats with metoclopramide. The therapeutic effects of the three plant extracts were determined by hormone levels (PRL, FSH, LH, EST, PRG, and TEST) and it was found that they are close to their normal value in rat serum given by these plant extracts compared to the positive and negative control groups, as well as knowing their efficiency compared to the drug used for treatment Lactodel. The effect is due to estrogen receptors or dopamine receptors., the effect of alcoholic extracts of marjoram leaves, celery seeds, sage leaves, and the medicine (bromocriptine) had the same effect and effectiveness in males on the hormone prolactin, unlike the female, so the effect of the alcoholic extract of marjoram leaves and celery seeds and the medicine (bromocriptine) had the same effect, but the alcoholic extract of sage leaves was less effective than them in lowering the hormone prolactin. This therapeutic effect of these 


\section{Effect of Some Plant Extracts on Hyperprolactinemia in Experimental Animals}

extracts is due to the fact that they contain phytoestrogens that have an effect on estrogen receptors and / or substances that act on dopamine receptors of the type D2, where they bind to dopamine receptors on the membrane located on the cell membrane in the lactotroph, which leads to their activation and then leads to a reduction Prolactin secretion.

\section{References}

Agovic, S; Elena, YA; Theodore, IL; Shailesh, PB (2008) Mechanisms for metoclopramide-mediated sensitization and haloperidol-induced catalepsy in rats: European J of Pharmacology 587, 181-186.

Al-Asmari, AK; Athar, MT; Kadasah, SG (2017) An updated phytopharmacological review on medicinal plant of Arab Region: Apium graveolens Linn. Pharmacognosy Review 11, 13-18.

Amaral, C; Gustavo ARM; Katia, CC; Rodrigo, RM; Jose, MSJr; Edmund, CB (2013) Metoclopramideinduced hyperprolactinemia effects on the pituitary and uterine prolactin receptor expression: General and Comparative Endocrinology 189,105-110.

Ben-Jonathan, N; Hugo, ER; Brandebourg, TD; LaPensee, CR (2006) Focus on prolactin as a metabolic hormone. Trends Endocrinol Metab 17, 11016.

Bisset, NG; Wichtl, M (2001) Herbal Drugs and Phytopharmaceuticals: A Handbook for Practice on a Scientific Basis with Reference to German Commision E Monographs. $2^{\text {nd }}$ ed. Boca Raton, FI: CRC Press; pp 440e443.

Brue, T; Delemer, B (2007) French Society of Endocrinology (SFE) work group on the consensus on hyperprolactinemia, Diagnosis and management of hyperprolactinemia: expert consensus - French Society of Endocrinology, Ann Endocrinol 68, 58-64.

Casanueva, FF; Molitch, ME; Schlechte, JA; Abs, R; Bonert, V; Bronstein, MD; Brue, T; Cappabianca, P; Colao, A; Fahlbusch, R; Fideleff, H; Hadani, M; Kelly, P; Kleinberg, D; Laws, E; Marek, J; Scanlon, M; Sobrinho, LG; Wass, JAH (2006) Giustina, Guidelines of thepituitary society for the diagnosis and management of prolactinomas, Clin Endocrinol 65, 265-273.

Falkenius-Schmidt, K; Rydmarker, S; Horner, KC (2005) Hyperprolactinemia in some Me'nie're patients even in the absence of incapacitating vertigo:
Clinical Research Council, Kristianstad, Scania Region and from A" ngelholm Hospital, Sweden 203, 154-158.

Haddad, PM; Wieck, A (2004) Antipsychotic-induced hyperprolactinemia: mechanisms, clinical features, and management. Drugs 64, 2291-2314.

Harrington, RA; Hamilton, CW; Brogden, $\mathrm{RN}$; Linkewich, JA; Romankiewicz, JA; Heel, RC (1983) Metoclopramide: J of Clinical Immunology 25, 451-494.

Iván, G; Nikoletta, Szigeti-Csúcs, MO; Cyörgy, MN; Miklós, I; Góth (2005) Treatment of pituitary tumors. International $\mathrm{J}$ of Basic and Clinical Endocrinology Endocrine 28, 101-110.

Jackson, RD, Wortsman, J; Malarkey, WB (1985) Macroprolactinemia presenting like a pituitary tumor. Am J Med 78, 346-350.

Mancini, T; Casanueva, FF; Giustina, A (2008) "Hyperprolactinemia and prolactinomas". Endocrinology and Metabolism Clinics of North America 37, 67-99.

MX, LH; Liu, YLF; Wang, PRZ; Zang, P (2015) AntiHyperprolactinemic Effect of Formula Malt Decoction, a Chinese Herbal Cocktail. Tropical $J$ of Pharmaceutical Research 14, 263-269.

Ovodova, RG; Golovchenko, VV; Popov, VS; Popova, GY; Paderin, NM; Shashkov, AS; Ovodov, YS (2009) Chemical composition and anti-inflammatory activity of pectic polysaccharide isolated from celery stalks. Food Chemistry 114, 610-615.

Perry, EK; Pickering, AT; Wang, WW; Houghton, PJ; Perry, NS (1999) Medicinal plants and Alzheimer's disease: from ethnobotany to phytotherapy. $J$ Pharm Pharmacol 51, 527e534.

Potty, K (2001) Marjoran. In: Peler, K.V. (Ed.), Handbook of Herbs and Spices. Woodhead Publishing Limited, England pp. 216-237.

Prerna, A; Vasudeva, N (2015) Origanum majorana L. phoyto-pharmacological research. Ind $\mathrm{J}$ Nat Prod Resour 6, 261-267.

Harrington, RA; Hamilton, CW; Brogden, RN; Linkewich, JA; Romankiewicz, JA; Heel RC (1983) Metoclopramide: J of Clinical Immunology 25, 451494.

Sarah, S; Tae-Yon, C; Wesley, GG (1998) Phytoestrogens Act as Estrogen Agonists in an EstrogenResponsive Pituitary Cell Line, Toxicology and Applied Pharmacology 152, 41-48. 
Shun-Li, Z; Hai-Bin, T; Jin-Tao, H; Zhen-Le, Z; Xiao, D; Song, L; Hui, Y (2019) PGAM5-CypD pathway is involved in bromocriptine-induced RIP3/MLKLdependent necroptosis of prolactinoma cells: Biomedicine Pharmacotherapy 111, 638-648.

Snedecor, GM; Cochran WG (1980) Statistical methods, Sixth Edition, lowa State Univ Press, Amer lowa, USA.

Toru, O; Toshiaki, K; Yasuhiko, I; Yuki, TT; Tetsuhiro, N; Akinori, A (2008) Bromocriptine, a dopamine D2 receptor agonist with the structure of the amino acid ergot alkaloids, induces neurite outgrowth in PC12 cells: European $J$ of Pharmacology 598, 27-31.

Tsai, JC; Tsai, S; Chang, WC (2004) Effect of ethanol extracts of three Chinese medicinal plants with laxative properties on ion transport of the rat intestinal epithelia. Biol Pharm Bull 27, 162.

Yusni, Y; Zufry, H; Meutia, F; Sucipto, KW (2018) The effects of celery leaf (Apium graveolens L.) treatment on blood glucose and insulin levels in elderly pre-diabetics. Saudi Medical J 39, 154-160. 


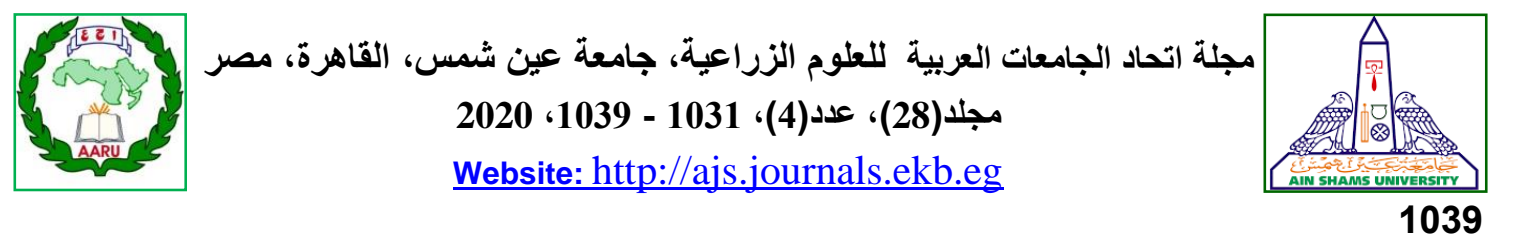

تأثير بعض المستخلصات النباتية على البرولاكتين المرتفع في حيوانات التجارب

[72]

$$
\begin{aligned}
& \text { عنان عاطف محمد محمد" - مجدى فؤاد توفيق - همت عبد الفتاح ابراهيم - }
\end{aligned}
$$

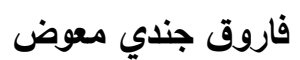

$$
\begin{aligned}
& \text { قسم الكيمياء الحيوية - كلية الزراعة - جامعة عين شمس - ص.ب } 68 \text { - حدائق شبرا } 11241 \text { - القاهرة - مصر }
\end{aligned}
$$

*Corresponding author: Ananatef1994@gmail.com

أظهرت النتائج أن عقار ميتوكلوبراميد (150 مجم / كجم

/ يوم) لمدة أسبوع كان له تأثير فيتوبران في مجموعة التحكم

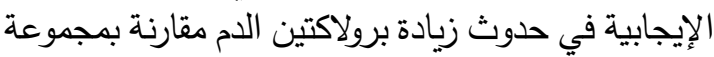

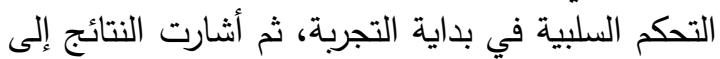

وجود تأثير معنوي (P>0.05) لجميع المستخلصات

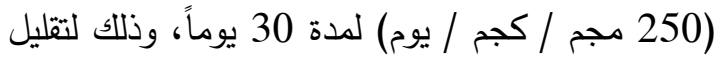

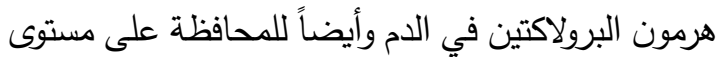

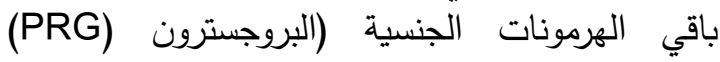
والإستروجين (E2) والتستوستيرون (TST) والئنست (TST) والهرمون

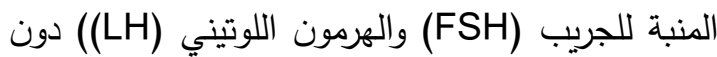
التسبب في أي اضطراب عند الذكور والإناث مقارنة

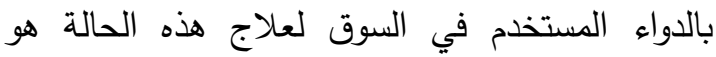

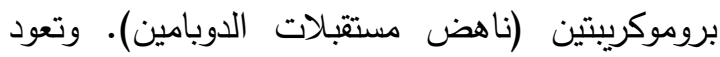

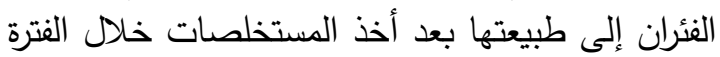

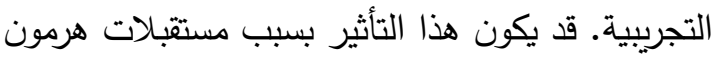
الاستروجين اومستقبلات الدوبامين.
زيادة برولاكتين الدم هو حدوث اضطراب في الغدد

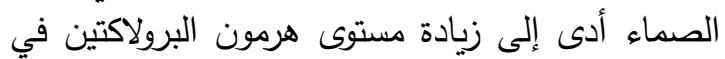

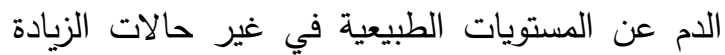

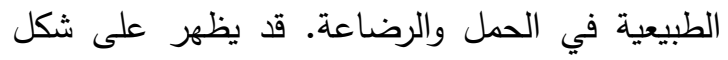

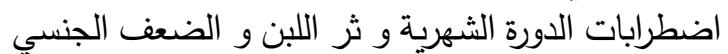
والتثذي والعقم وانخفاض كثافة المعادن في العظام

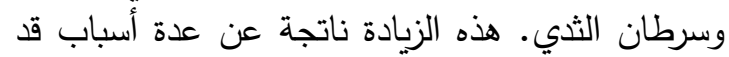

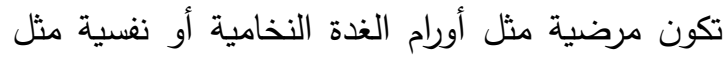

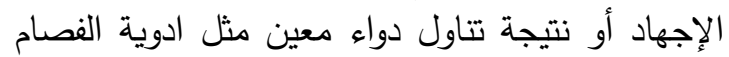

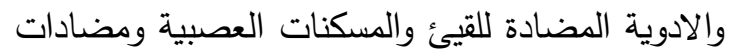

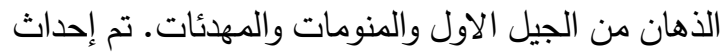
زيادة برولاكتين الدم بواسطة الميتوكلوبراميد في ذكور الإن المات

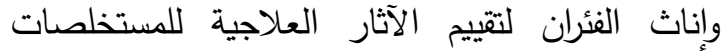

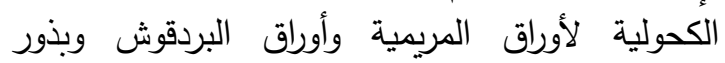
الكرفس. من خلال التحليل الكيميائي لهرمونات الدافي التردئ 